\title{
The Effect of Environment On the Concentrations of Sodium and Potassium in The Serum and Urine of Dromedary Camel
}

\author{
Amer M Hussin* \\ Anatomy Department, College of Veterinary Medicine, Baghdad University, Baghdad, Iraq
}

"Corresponding author: Amer M Hussin, Assist. Prof. Anatomy Department, College of Veterinary Medicine, Baghdad university, Baghdad, Iraq. Email: amer_hussain42@yahoo.com

Citation: Hussin AM (2017) The Effect of Environment On the Concentrations of Sodium and Potassium in The Serum and Urine of Dromedary Camel. Arch Vet Sci Technol: AVST-127. DOI:10.29011/AVST-127/100027

Received Date: 30 July, 2017; Accepted Date: 30 August, 2017; Published Date: 08 September, 2017

\begin{abstract}
Samples of blood and urine were collected from (43) young dromedary camels from Al-Najaf province of Iraq in summer and winter in 2016. Biochemical analysis of these samples was carried out on sodium $(\mathrm{Na})$ and potassium $(\mathrm{K})$. The result revealed that the values of sodium and potassium were more in summer time than winter time in blood and urine samples. The ratio of $\mathrm{Na} / \mathrm{K}$ was more in summer time than in winter time. The $\mathrm{Na} / \mathrm{K}$ ratio of the serum was 3.4 times than that of the urine. The result found that the values of $\mathrm{Na}$ and $\mathrm{K}$ were more in the urine than the serum. The study regarded the increase of electrolytes in the body of the camel, against hot environment, as an acclimatization mechanism. The study concluded that the camel behaves, in hot environment, as a hypertonic mass to save the water in his body.
\end{abstract}

Keywords: Blood; Camel, Potassium; Sodium; Urine

\section{Introduction}

Guyton (1981) [2] reported that the sodium was the main ion that forms and keeps the size of the extracellular fluid and the osmotic pressure. Coles (1986) [3] stated that the Na values in the serum of ruminants were $132-152 \mathrm{ml} \mathrm{Eq} /$ liter, while the $\mathrm{K}$ values were 3.91-5.8 mlEq/ liter, and the value of Na elevated after dehydration. Choudhary et al. (1995) [4] found that the Na level in dromedary camel was $152.85 \pm 6.30$ and the $\mathrm{K}$ level was $4.53 \pm 0.26$. Dehydration leads to decrease the blood plasma size and consequently elevation in the $\mathrm{Na}$ concentration from $154 \pm 2$ to $191 \pm 3$ in dromedary camels in Morocco [5]. Toma and Al-lami (2000) [6] found, in their study on Iraqi mountain goat, that $\mathrm{Na}$ ion concentration in the serum in summer time was higher than in winter time, while $\mathrm{K}$ ion registered lower values in summer time compared to winter time. On the other hand, Wang-Q et al 1996 reported that the $\mathrm{Na}$ in Bactrian camel was low. El -tahir et al. (2010) [7] reported that the serum elements of dromedary camels ranges were 97.8-246.1 mEq/liter for $\mathrm{Na}$ and 3.22- $8.70 \mathrm{mEq} / \mathrm{liter}$ for $\mathrm{K}$.

\section{Materials and Methods}

\section{Animals}

Forty-three healthy male camels of 1-4-year-old were collected from Abattoir of Al-Najaf Province, Iraq in Summer and winter times.

\section{Blood samples}

Blood samples were collected from jugular veins after slaughtering at 4-7 AM. Blood samples were collected in serum collection tubes and the serum was separated by centrifugation at $2500 \mathrm{RPM}$, then preserved at $-18^{\circ} \mathrm{c}$. Serum analysis was carried out after 3-4 hours of collection.

\section{Urine samples}

Urine samples were collected from the urinary bladder directly after slaughtering. Urine samples were collected in sterilized clean tubes

\section{Biochemical analysis}

Serum or urine samples were analyzed for concentrations of $(\mathrm{Na})$ and $(\mathrm{K})$. Flame photometer was used for measurement of concentrations of these two electrolites ( $\mathrm{ml} \mathrm{Eq} / \mathrm{liter}$ ) according to Wooton 1964 [1]. By mixing $0.2 \mathrm{ml}$ of urine or blood with $19.8 \mathrm{ml}$ of distilled water to get dilution factor of 1:100, then put it in the instrument and compared with the standard solutions of the instrument. The stock standard sodium was prepared by dissolving $11.69 \mathrm{gm}$ of $\mathrm{Na}$ chloride in one liter of distilled water while the 


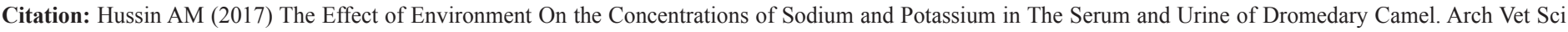
Technol: AVST-127.

stock standard $\mathrm{K}$ was prepared by dissolving $0.74 \mathrm{gm}$ of $\mathrm{Kcl}$ in one liter of distilled water. Then the instrument reading was used in this equation

The concentration of serum or urine $(\mathrm{ml} \mathrm{Eq} /$ liter $)=$ The reading $\mathrm{x} 100$

\section{Results and Discussion}

The two elements, $\mathrm{Na}$ and $\mathrm{K}$, work together to keep animal body balanced. Animal body need $\mathrm{Na}$ to maintain proper ionic balance in fluids and tissues. Water follows $\mathrm{Na}$, and any $\mathrm{Na}$ deficiency might lead to dehydration [8]. The current study found that both $\mathrm{Na}$ and $\mathrm{K}$ were significantly affected by the environmental changes, as both electrolites were significantly elevated in blood and urine during summer time compared to winter time, however, the $\mathrm{Na} / \mathrm{K}$ ratio was higher in summer compared to winter. This was similar to the findings of Pandy and Roy 1969 [9] in Indian buffaloes and Ghosal et al. 1973 [10] in Indian camels. Moreover, the $\mathrm{Na} / \mathrm{K}$ ratio of the serum was 3.4 times than the ratio of the urine (Table 1 and 2). The study also agreed with Yagil et al 1975, Guyton 1981 [11] and Ali et al 2012 [12] who stated that dehydration leads to elevate the $\mathrm{Na}$ level in the serum of the camel to keep the water in his body and agreed with Al-Janabi and Al- Jalili 1990 [8] who reported that $\mathrm{Na}$ level elevated in the blood due to increase its absorption from the intestine. The values of the present study were within the range of the findings of El-Tahir et al 2010 [7]. On the other hand, the study was in variance with Blinco and Brody 1951 [13] and Kamal et al 1962 [14] who reported that there were no significant differences in the values of $\mathrm{Na}$ and $\mathrm{K}$ in the plasma of cattle during elevation of temperature. The study partly agreed with Yagil and Berlyne 1976 [15] who registered only $\mathrm{Na}$ level elevation in the urine during dehydration followed by rapid.

Rehydration while $\mathrm{K}$ metabolism was not elevated, and with Toma and Al-Lami 2000 [6] who registered $\mathrm{Na}$ ion elevation in the serum of mountain goat. Vander 1980 [16] hypothesized that in summer time, camel increases the electrolytes of the serum in order to regulate and acclimate extra cellular fluids especially the volume of the blood and plasma compared to intra and inter cellular fluids by means of the osmotic gradient. This explained by increasing the size of the plasma and decreasing the intracellular fluids compared to other animals. The study regarded the increase of electrolytes in the body of the camel, against hot environments, as an acclimatization mechanism. The study concluded that the camel behaves, in his environment, as a hypertonic mass to save the water in his body.

\begin{tabular}{|c|c|c|c|c|}
\hline \multirow{2}{*}{ Season } & \multirow{2}{*}{$\begin{array}{c}\text { No. of } \\
\text { Animals }\end{array}$} & \multicolumn{3}{|c|}{ Serum } \\
\hline & & $\mathbf{N a}$ & $\mathbf{K}$ & $\mathrm{Na} / \mathrm{K}$ Ratio \\
\hline Winter & 25 & $108 \pm 8.42^{*}$ & $5.74 \pm 0.26^{*}$ & 18.8 \\
\hline Summer & 18 & $143 \pm 1.34^{*}$ & $6.6 \pm 0.24^{*}$ & 21.7 \\
\hline
\end{tabular}

Table 1: Showing the effect of season on the concentration of minerals in the serum of Camel.

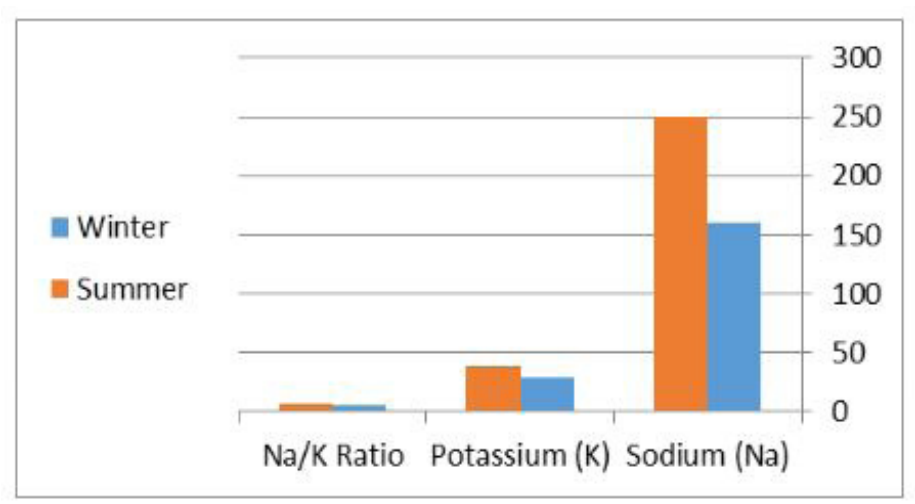

Figure 1: Showing the effect of season on the concentration of minerals in the serum of Camel.

\begin{tabular}{|c|c|c|c|c|}
\hline \multirow[b]{2}{*}{ Season } & \multirow{2}{*}{$\begin{array}{c}\text { No. of } \\
\text { Animals }\end{array}$} & \multicolumn{3}{|c|}{ Urine } \\
\hline & & $\mathrm{Na}$ & $\mathrm{K}$ & $\begin{array}{l}\mathrm{Na} / \mathrm{K} \\
\text { Ratio }\end{array}$ \\
\hline Winter & 25 & $159.84 \pm 25.55^{*}$ & $28.50 \pm 3.01^{*}$ & 5.6 \\
\hline Summer & 18 & $249.9 \pm 29.2^{*}$ & $38.98 \pm 3.07^{*}$ & 6.4 \\
\hline
\end{tabular}

Table 2: Showing the effect of season on the concentration of minerals in the urine of Camel. 
Citation: Hussin AM (2017) The Effect of Environment On the Concentrations of Sodium and Potassium in The Serum and Urine of Dromedary Camel. Arch Vet Sci Technol: AVST-127.

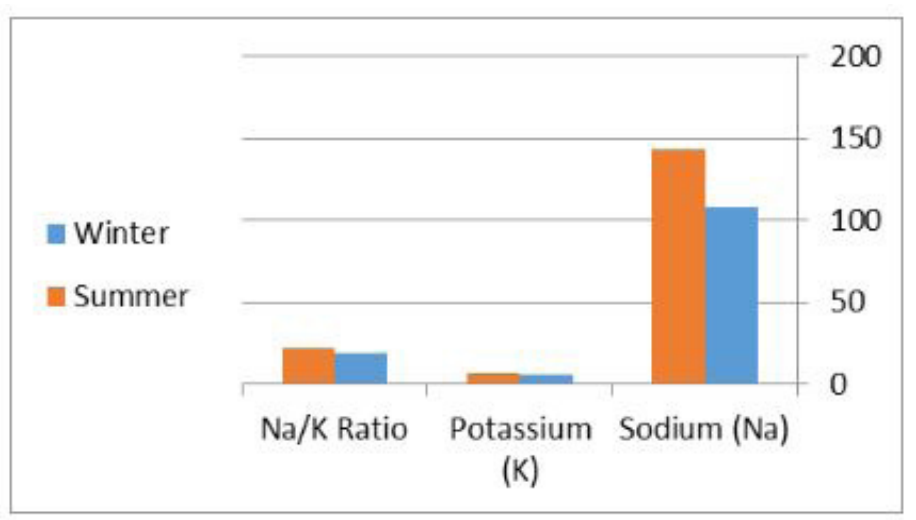

Figure 2: Showing the effect of season on the concentration of minerals in the urine of Camel.

\section{References}

1. Wooton IOP (1964) Microanalysis in medical biochemistry. In: $4^{\text {th }}$ ed. Churchill Livingstone Ltd. London.

2. Guyton AC (1981) Textbook of medical physiology. In: 6th ed. Saunders W.B. Company. Philadelphia.

3. Coles EH (1986) Veterinary clinical pathology. In: 4th ed. W.B. Saunders Company, Philadelphia.

4. Choudhary GR, Purohit NR, Dudi PR, Sharma CK, Chouhan DS, et al. (1995) Retention of urine in camels (Camelus dromedaries): hematological and biochemical alterations. J Camel Pract Res 2: 115-118.

5. Bengoumi M, Riad F, Giry J, de la Farge F, Safwate A, et al. (1993) Hormonal control of water and sodium in plasma and urine of camels during dehydration and rehydration. Gen Comp Endocrinal 89: 378386 .
6. Toma B, El-Lamy AD (2000) Seasonal changes in hematological, biochemical, and physiological parameters of Ibex (Capra ibex) in Iraq. J Vet Sci 13: 51-59.

7. El-Tahir YE, Ali HM, Mansour MH, Mahgob O (2010) Serum Mineral contents of the omani Racing Arabian camels (Camels dromedarias). Journal of Animal and Veterinary Advances 9: 764-770.

8. Al-Janabi AS, Al-Jalili ZF (1990) Camels, Its characteristics and physiology. Education press. Baghdad.

9. Pandey MD and Roy A (1969) Studies on the adaptability of buffalo to tropical climate. Indian J Anim Sci 39: 367-377.

10. Ghosal AK, Appanna TC, Dwaraknath PK (1973) A note on studies on the seasonal variation in serum electrolytes in Indian Camel (Camelus dromedaries). Indian J Anim Sci 43: 558-559.

11. Yagil R, Etzion Z, Berlyne GM (1975). Acid-Base parameters in the dehydrated camels. Tydschr Diergeneesk 100: 1105- 1108.

12. Ali MA, Adem A, Chandranath IS, Benedict S, Pathan JY, et al. (2012) Responses to dehydration in the One-Humped camel and effects of blocking the renin-angiotensin system. Plos One 7: 37299.

13. Blinco C, Brody S (1951) Influence of temperature on blood composition of cattle. Res Bull 488 Mo Agric Exp Stn: 48.

14. Kamal TH, Johnson HD, Ragsdale's AC (1962) Metabolic reactions during thermal stress (35 to 95 ) in dairy animals acclimated at 50 and 80. Res Bull 785 Mo Agric Exp St: 114.

15. Yagil R, Berlyne GM (1976) Sodium and Potassium metabolism in the dehydrated and rehydrated Bedouin camel. J Appl Physiol 41: 457461.

16. Vander AJ (1980) Renal physiology. In: $2^{\text {nd }}$ ed. Mc Graw Hill Company. 